\title{
Differential regulation of the apoptotic machinery during megakaryocyte differentiation and platelet production by inhibitor of apoptosis protein Livin
}

\author{
I Abd-Elrahman ${ }^{1}$, V Deutsch², M Pick ${ }^{1}$, S Kay ${ }^{2}$, T Neuman $^{3}$, R Perlman ${ }^{1}$ and D Ben-Yehuda ${ }^{*, 1}$
}

Livin is a member of the inhibitor of apoptosis proteins (IAP) family of intracellular antiapoptotic proteins that act by binding and inhibiting caspases. Upon strong apoptotic stimuli, it is then specifically cleaved by caspases to produce a truncated protein (tLivin) with a paradoxical proapoptotic activity. Intriguingly, we have detected robust protein levels of Livin in normal mature bone marrow megakaryocyte (MK) and platelets. To evaluate the potential role of Livin in thrombopoiesis, we used the human BCR-ABL + cell line, LAMA-84, and cord blood CD34 + cells to induce differentiation toward MKs. Upon differentiation, induced by phorbol myristate acetate and concurrent with increase in Livin protein expression, LAMA-84 cells formed functional plateletlike particles. Livin overexpression in CD34 + progenitor cells induced higher endoreplication in the MKs generated. Furthermore, overexpression of Livin increased the ability of both primary MKs and differentiated LAMA-84 cells to produce functional platelets. In the differentiated LAMA-84 cells, we observed accumulation of proapoptotic thivin concomitant with increased caspase-3 activity. Downregulation of Livin with small interfering RNA in both leukemic and primary MK cells decreased their ability to produce functional platelets. We suggest that Livin has a role in thrombopoiesis by regulating the apoptotic and antiapoptotic balance in MK endoreplication and platelet production.

Cell Death and Disease (2013) 4, e937; doi:10.1038/cddis.2013.454; published online 28 November 2013

Subject Category: Experimental Medicine

The final stages of megakaryocyte (MK) differentiation is platelet production, which is a complex process whose mechanisms are yet to be understood. ${ }^{1}$ In the bone marrow (BM), MKs give rise to circulating platelets through commitment of the multipotent stem cell to the MK lineage, proliferation of the progenitors and terminal differentiation of MKs and producing platelets. This process is characterized by DNA endoreplication, in which the cellular DNA content can reach up to $128 N^{2}$ followed by cytoplasmic maturation and expansion. Complex changes in the organization of the cytoskeleton allow the production of cytoplasmic pseudopodial extensions. ${ }^{3}$ These proplatelets are extruded into the circulation where shear forces trigger their fragmentation, resulting in the release of platelets. ${ }^{4,5} \mathrm{~A}$ number of studies propose that during late megakaryocytic maturation there are relationships between activation of the intrinsic apoptotic pathway and platelet production ${ }^{6}$ and the modulation of platelet survival. ${ }^{7,8}$ Interestingly, there is a distinct accumulation of caspases in mature MKs and platelets: caspase-3 and -9 are active in terminally differentiated MKs but only caspase- 3 is abundant in platelets, ${ }^{9}$ with cytochrome $c$ detected in the cytosol of MKs that contain activated caspases. ${ }^{10}$ Moreover, it has been observed that the pancaspase inhibitor, z-VAD.fmk ( $N$-benzyloxycarbonyl-Val-Ala-Asp(O-Me) fluoromethyl ketone), inhibits proplatelet formation and the production of platelets in the human megakaryocytic cell line MEG-01. ${ }^{9}$ In addition, recent studies showed an induction of the intrinsic apoptotic pathways during in vitro platelet activation. ${ }^{11}$ The apoptosis-inhibitory protein $\mathrm{Bcl}-2$ (B-cell lymphoma 2) is expressed in early MKs and is downregulated with MK differentiation. In accordance, ectopic overexpression of Bcl-2 in MK inhibits proplatelet formation. ${ }^{10,12,13}$ Deletion of the proapoptotic Bcl-2-related protein, Bim, leads to a significant decrease in platelet production. ${ }^{14}$ In addition, the antiapoptotic B-cell lymphoma-extra large (Bcl-xL) protein is highly expressed in the early and mid-stages of the differentiation. ${ }^{15,16}$ Deletion of $\mathrm{Bcl}-\mathrm{xL}$ results in MK apoptosis and a failure of platelet shedding. ${ }^{17}$ However, overexpression of $\mathrm{Bcl}-\mathrm{xL}$ results in impaired platelet release. ${ }^{12}$ These findings further support the differential regulation of the apoptotic machinery during MK differentiation and platelet production. However, an increase in apoptosis does not lead to higher

\footnotetext{
${ }^{1}$ Division of Hematology, Hadassah-Hebrew University Medical Center, Jerusalem, Israel; ${ }^{2}$ The Hematology Institute, Tel Aviv Medical Center, Tel-Aviv Israel and ${ }^{3}$ Department of Pathology, Hadassah-Hebrew University Medical Center, Jerusalem, Israel

*Corresponding author: D Ben-Yehuda, Division of Hematology, Hadassah-Hebrew University Medical Center, Jerusalem 91120, Israel. Tel: +972 2 6776744/8; Fax: +972 2 6423067; E-mail: dbyehuda@ hadassah.org.il

Keywords: megakaryocyte differentiation; thrombopoiesis; apoptosis; inhibitor of apoptosis proteins; Livin; thivin

Abbreviations: Ac-DEVD-pNA, N-acetyl-Asp-Glu-Val-Asp-p-nitroaniline; ADP, adenosine 5'-diphosphate; Asp, aspartic acid; Bcl2, B-cell lymphoma 2; Bcl-xL, B-cell lymphoma-extra large; BIR, baculovirus IAP repeat; BM, bone marrow; cIAP, cellular inhibitors of apoptotic proteins; Diablo, direct IAP binding protein with low pl; HtrA, high temperature requirement protein A2; IAP, inhibitor of apoptosis protein; MK, megakaryocyte; PLP, platelet-like particles; PMA, phorbol myristate acetate; RING, really interesting new gene; SCF, stem cell factor; siRNA, small interfering RNA; Smac, second mitochondria-derived activator of caspase; TPO, thrombopoietin; XIAP, X-linked inhibitor of apoptosis protein; z-VAD.fmk, N-benzyloxycarbonyl-Val-Ala-Asp(O-Me) fluoromethyl ketone

Received 11.8.13; revised 04.10.13; accepted 04.10.13; Edited by A Finazzi-Agró
} 
levels of platelet production. Indeed, recent description of an apoptosis-enhancing cytochrome $c$ mutation causes thrombocytopenia in individuals carrying it. This mutation causes premature release of platelets from MKs both in vivo and in vitro. ${ }^{18}$

Surprisingly, two recent studies suggest that the intrinsic apoptosis pathway is not required for platelet formation. ${ }^{17,19}$ First, in mice, the combined deletion of both proapoptotic BAK1 and BAX proteins does not affect platelet formation. ${ }^{17}$ The second study shows that although caspase-9 is required for the efficient death of MKs and platelets, lack of caspase- 9 does not affect the steady state of thrombopoiesis and platelets' function. These results indicate that activation of caspase- 9 pathway is required for the efficient death of MKs and platelets rather than platelet production. ${ }^{19}$ Winkler et al. ${ }^{20}$ found that the proapoptotic proteins Omi/HtrA2 (high temperature requirement protein $\mathrm{A} 2$ ) and Smac/Diablo (second mitochondria-derived activator of caspase/direct inhibitor of apoptosis protein binding protein with low pl) are released from the mitochondria upon induction of platelet apoptosis. Inhibition of Omi/HtrA2 during platelet apoptosis decreased the level of activated caspase-3/7 and caspase- 9 , but not of caspase- $8{ }^{20}$ As a result, MKs require a functional intrinsic mitochondrial apoptosis pathway to enable endoreplication that is restrained somewhat at the stage of platelet production, ${ }^{17}$ and thus there should be a balance between apoptotic and antiapoptotic events to generate robust levels of platelets by MKs.

Smac/Diablo and Omi/HtrA2 are two antagonists of the IAP proteins. $^{21-24}$ The IAP family has become increasingly prominent in the field of apoptosis. IAPs are able to inhibit apoptosis induced by a variety of stimuli mainly by binding and inhibiting specific caspases, primarily 3,7 and $9 .{ }^{25}$ Eight human IAPs have been identified: C-IAP1, c-IAP2, NAIP, survivin, XIAP (X-linked inhibitor of apoptosis protein), Bruce, ILP-2 and Livin (ML-IAP). IAP family members contain one or more highly conserved 70-amino-acid baculovirus IAP repeats (BIR). The BIR domain was shown to have a role in the antiapoptotic function of IAPs. ${ }^{26,27}$ In addition, the BIR domain has a regulatory function as the binding site of several IAP antagonists such as SMAC/Diablo and HtrA2. ${ }^{24}$ Some human IAPs also contain a conserved zinc-binding motif known as the RING (really interesting new gene) domain. ${ }^{28}$ The IAP Livin contains a single BIR domain at the $\mathrm{N}$ terminus and a carboxy-terminal RING domain. ${ }^{29-31}$ We found that Livin encodes two splicing variants, termed Livin $\alpha$ and Livin $\beta$. The two proteins are identical, except for 18 amino acids located between the BIR and the RING domains, which are present in the Livin $\alpha$ isoform but not in the Livin $\beta$ isoform. Both isoforms share similar antiapoptotic properties. However, despite the high similarity, we have shown different antiapoptotic properties of the two isoforms. ${ }^{29} \mathrm{We}$ also found that Livin is specifically cleaved after the aspartic acid 52 (Asp52) residue to produce a truncated protein, tLivin, that not only loses Livin's antiapoptotic activity but also acquires a proapoptotic effect. ${ }^{32,33}$ Thus, Livin is unique among the IAP members, exerting both anti- and proapoptotic activities, making it a regulator of apoptosis rather than an antiapoptotic protein. $^{32,33}$
This study is the first reported evidence of Livin expression in MKs and platelets, and thus an in vitro model was established to evaluate the potential role of Livin in thrombopoiesis. The human stem cell line LAMA-84 and primary cord blood CD34 + cells were induced to differentiate to MKs. Upon differentiation, cultures of MKs produced proplatelets and functional platelet-like particles (PLP) capable of aggregation and activation. This thrombopoiesis was accompanied by the upregulation of Livin protein levels as well as the proapoptotic tLivin. Furthermore, overexpression of the Livin-RING mutant that lacks the proapoptotic activity of tLivin, in both CD34+ and LAMA-84-differentiating cultures, decreased the ability of the generated MKs to produce functional platelets.

\section{Results}

Livin is expressed in MKs and platelets. Livin expression was examined in human BM by immunohistochemistry using a purified monoclonal antibody. ${ }^{34}$ Livin was detected in the cytoplasm of mature BM MKs and in myeloid precursors (Figures 1a (control) and b), which are unequivocally recognizable by their morphologic criteria (giant size and polyploidization of the nucleus in the cell). Livin expression was also demonstrated in MKs of patients with various hematological diseases such as immune thrombocytopenic purpura (Figure 1c), myelodysplastic syndrome, Hodgkin's lymphoma, essential thrombocythemia and polycythemia vera (data not shown). Following this finding, we studied the presence of Livin proteins in platelets and found robust levels of both Livin $\alpha$ and $\beta$ protein in healthy donors using western blot analysis as compared with positive controls (Figure 1d).

The role of Livin in thrombopoiesis. Human primary MKs are difficult to isolate because of their low numbers in human samples. Thus we used a cell line, LAMA-84, with the potential to mature into MK just like human primary CD34 + hematopoietic progenitor cells. These cells, which originated from a patient with blast crisis chronic myeloid leukemia, can terminally differentiate into platelets in response to direct activation of intracellular signaling pathways, including protein kinase $\mathrm{C}$ and mobilization of intracellular calcium. ${ }^{35,36}$ The LAMA-84 cell line can also undergo differentiation toward the erythroid lineage, in response to Hemin. ${ }^{37}$

The effect of phorbol myristate acetate (PMA) on megakaryocytic differentiation of LAMA-84 cells was investigated. We used the markers CD41 to detect MKs and CD71 to detect erythroid cells. Ploidy, a marker of MK differentiation, was also determined. Morphological staining of differentiated LAMA-84 cells with May-Grunwald/Giemsa revealed a marked increase in cell size and extensive multinuclearity after PMA induction and proplatelet formation (Figure $2 \mathrm{a}$ ). A range of PMA concentrations was tested and differentiation was obtained between 0.6 and $10 \mathrm{ng} / \mathrm{ml} \mathrm{PMA} \mathrm{(data} \mathrm{not} \mathrm{shown).}$ Untreated cells were predominantly diploid (Figure $2 b$ ), but after 4 days of exposure to $5 \mathrm{ng} / \mathrm{ml}$ PMA, LAMA- 84 cells underwent polyploidization $(8 N, 16 N$ and $32 N)$ and full differentiation (Figures $2 a$ and $b$ ). 


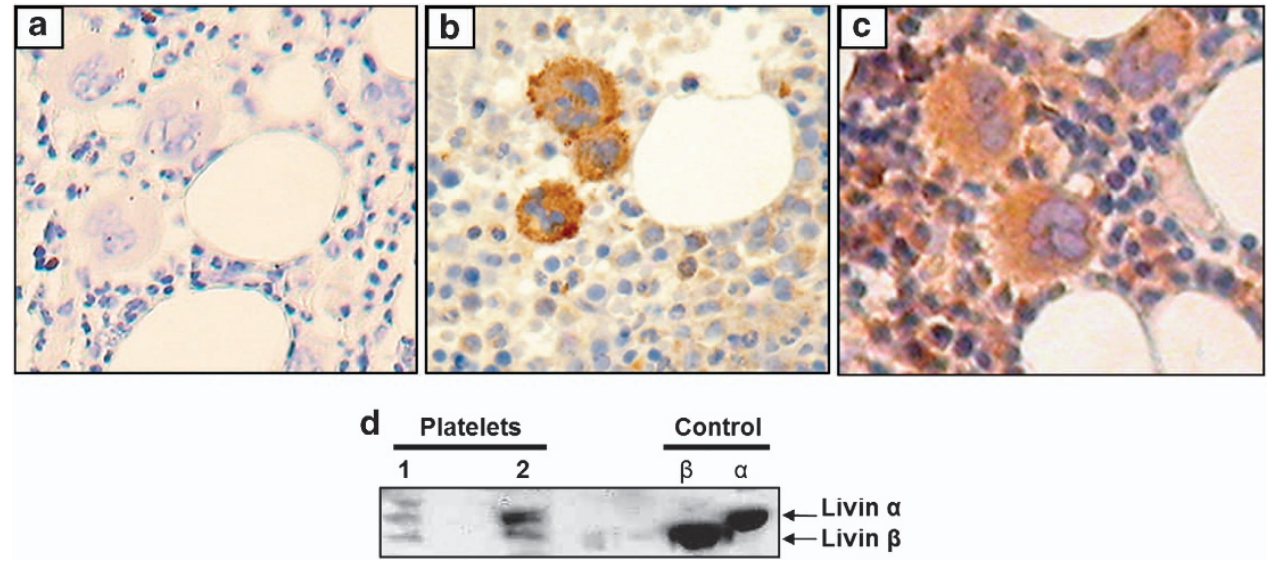

Figure 1 Normal human MKs and platelets express Livin. (a) BM stained with secondary antibody and hematoxylin without Livin antibody as control. (b) Livin was detected in myeloid precursors and mature MKs in normal BM stained with a Livin-specific antibody. (c) Livin expression in MKs of a patient with idiopathic thrombocytopenic purpura (ITP) (original magnification, $\times 20$ ). (d) The Livin protein was detected (by immunoprecipitation-western blot analysis) in platelets derived from the platelet concentrate (first two lanes). Both alternatively spliced variants of Livin, $\alpha$ and $\beta$, were overexpressed in LAMA-84 by transient transfection and used as a control (last two lanes) to compare endogenous Livin protein expression in platelets

a
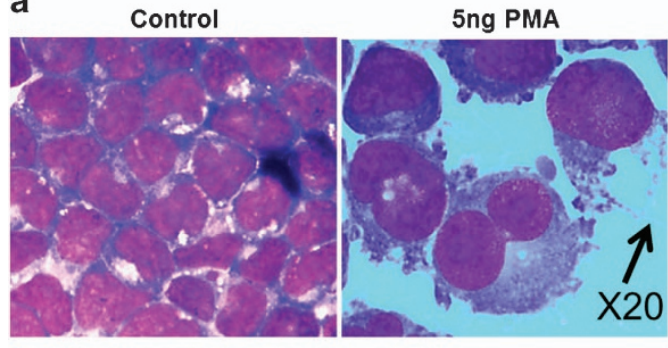

b

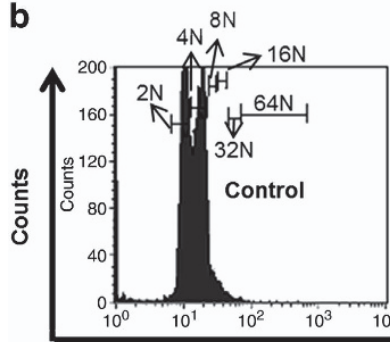

d

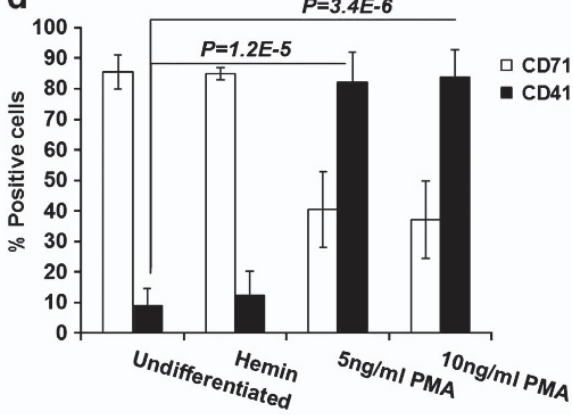

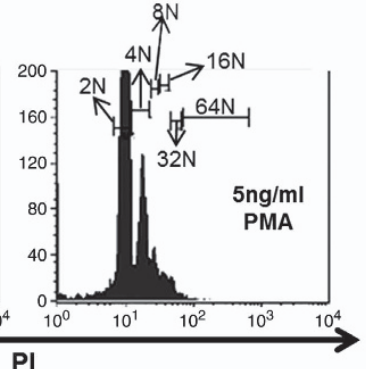

PI

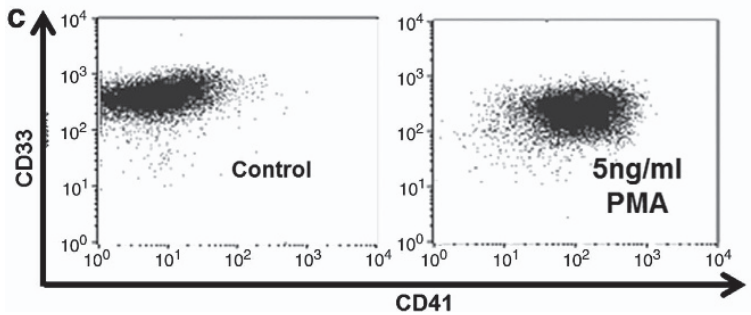

e
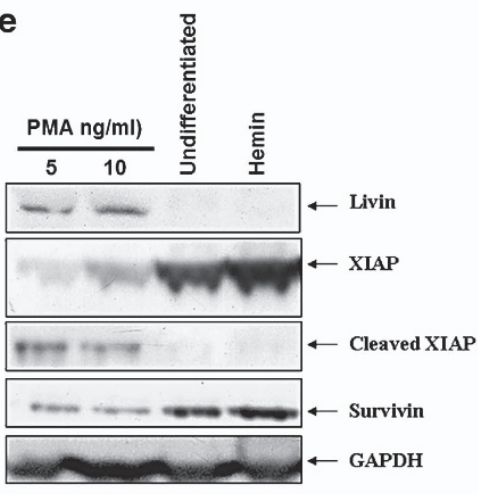

Figure 2 Differentiation induction of LAMA-84 cells. LAMA-84 cells $\left(0.5 \times 10^{6} / \mathrm{ml}\right)$ were induced to differentiate to MKs by PMA (1.25-10 ng/ml) for 4 days. (a) MayGrunwald/Giemsa staining of cytospin preparations of cells without PMA treatment and following exposure to PMA ( $5 \mathrm{ng} / \mathrm{ml})$. Note the proplatelet projections indicated by the arrow (original magnification, $\times 20)$. (b) Cells were stained with propidium iodide $(50 \mu \mathrm{g} / \mathrm{ml}$ ) and nuclear ploidy was measured by flow cytometry histograms from cultures without PMA and with PMA. (c and d) LAMA-84 cells $\left(0.5 \times 10^{6} / \mathrm{ml}\right)$ were cultured with PMA (5 or $\left.10 \mathrm{ng} / \mathrm{ml}\right)$ to induce MK differentiation or with $50 \mu \mathrm{M}$ Hemin to induce erythroid differentiation. Markers of MK differentiation, CD41 (MK marker) and CD71 (control early erythroid cell marker), were detected by flow cytometry $(n=4)$. Undifferentiated (control) cells or Hemin-treated cells were of erythroid phenotype CD71 +, whereas PMA-treated cells were primarily of the MK phenotype CD41 + . (e) Livin, survivin and XIAP protein levels in the undifferentiated and differentiated LAMA- 84 cells were evaluated by western blot. Note the appearance of Livin in PMA-treated cells $(n=3)$ 
PMA induced differentiation of LAMA-84 cells toward the MK lineage, whereas Hemin induced differentiation toward erythroid development. In the absence of PMA stimulation, most LAMA-84 cells were CD71 + CD41 - . However, after 4 days of incubation with 5 or $10 \mathrm{ng} / \mathrm{ml}$ PMA, the cells acquired high levels of CD41 (Figure 2c), with an increase from $8.8 \pm 5.6$ to $81.9 \% \pm 10 \%(P=0.000012)$ (Figure $2 \mathrm{~d}$ ).

We analyzed the expression of antiapoptotic proteins of the IAPs family during the differentiation of LAMA-84 cells toward MKs by western blot analysis. The expression of Livin was not detected in untreated LAMA-84 cells, but was upregulated during PMA-induced differentiation toward the MKs lineage (Figure 2e). The LAMA-84 cells induced to differentiate toward erythroid lineage with Hemin did not regulate the levels of the antiapoptotic proteins of the IAP family (Figure 2e). In contrast to Livin, the levels of survivin decreased when cells were treated with PMA (Figure 2e). Upon differentiation of LAMA-84 cells into MKs, a dose-dependent significant decrease in the level of the fulllength form of XIAP was observed, accompanied by the appearance of the cleaved $30 \mathrm{kDa}$ fragment of XIAP that has a reduced ability to inhibit caspases ${ }^{38}$ (Figure $2 e$ ).

Livin induces PLP production in MKs. Proplatelet formation upon incubation of LAMA-84 cells with PMA (Figure 2a) suggests that PMA not only induces the cells to differentiate toward MKs and increases endoreplication but also induces terminal differentiation of the MKs into PLPs (Figure 3a). To determine whether PMA indeed induced terminal differentiation into PLPs, flow cytometric analysis was performed to determine the presence of CD41a + platelets released into the media. Normal platelets from peripheral blood were used to establish the forward scatter and side scatter gate analysis (Figure $3 b$ ) and a subsequent CD41a + gate for normal human platelets. As expected, the majority of blood-derived platelets expressed CD41a (Figure 3c). LAMA-84 cells
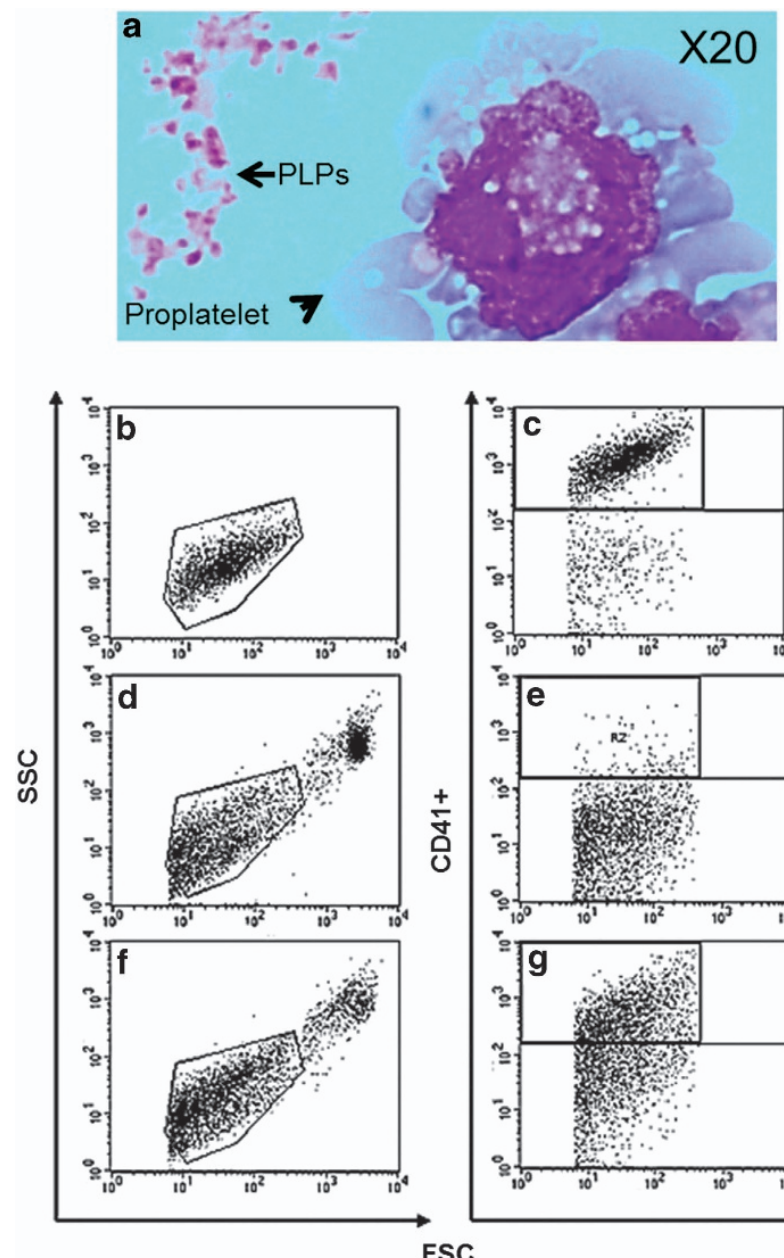

h

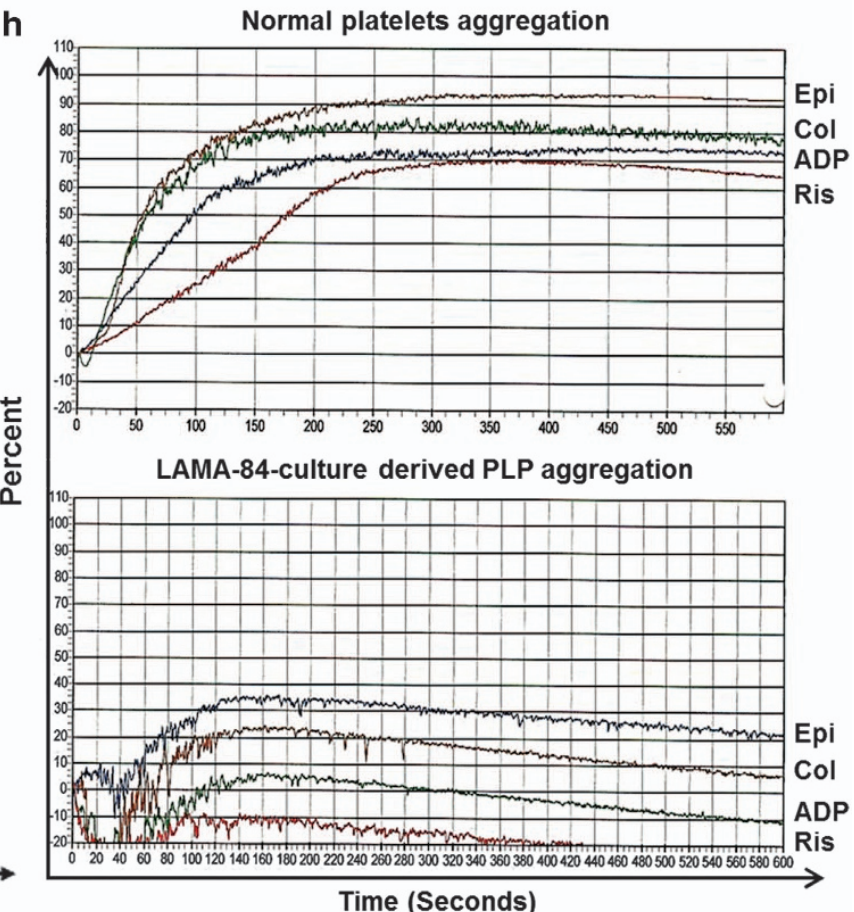

Figure 3 Functional PLPs are released to the culture medium from differentiating cells. LAMA-84 cells $\left(0.5 \times 10^{6}\right)$ were induced to differentiate to MKs by PMA $(5 \mathrm{ng} / \mathrm{ml})$. (a) On day 4, particles from cultured LAMA-84 cells were collected from media and stained with May-Grunwald/Giemsa. Both mature platelets and proplatelets are seen (original magnification, $\times 20$ ). (b) Normal platelets from peripheral blood were used to establish the forward/side scatter (FSC/SSC) gates using flow cytometric. (c) Subsequent gating of CD41+ normal platelets. (d) Platelets of untreated LAMA84 cells were gated according their physical characteristic FSC/SSC set by control platelets and (e) Subsequent CD41 gating of PLPs from untreated LAMA-84 culture supernatants. (f) PLPs of PMA-treated LAMA-84 cells were gated by FSC/SSC for normal platelets and (g) subsequently by CD41 staining of PLPs from PMA-treated LAMA-84 culture supernatants. (h) Aggregation of normal platelets (top) and LAMA-84-culture derived PLPs (bottom) in response to epinephrine (Epi), collagen (Col), ADP and ristocetin 
spontaneously released PLPs into the culture medium (Figure 3d) but only a minor proportion of PLPs in culture supernatants expressed CD41a $(6.5 \pm 2.2 \%)$ (Figure 3e). The percentage of PLPs released and platelets expressing CD41a was significantly increased following incubation with PMA (24.3 $\pm 3.6 \%$ ) (Figures $3 f$ and g). Taken together, these data indicate that CD41a + platelets were generated by PMA-induced LAMA-84 cells and released into the media. Aggregation, a functional test for platelet activation, was performed with the use of various agonists including epinephrine, collagen, adenosine $5^{\prime}$-diphosphate (ADP) and ristocetin on the culture-derived PLPs. These particles were capable of activation and aggregation, thus proving their functionality (Figures 3h).

Livin is cleaved during LAMA-84 differentiation into MKs. To study the mechanism of action of Livin, we stably overexpressed Livin in LAMA-84 cells and followed the Livin protein levels during MK differentiation (Figure 4a).

We and others have shown that Livin ${ }^{32}$ and XIAP $^{38}$ are specifically cleaved by effector caspases during apoptosis induced by various stimuli. As mentioned previously, caspases mediate the cleavage of Livin into a truncated form, tLivin, that is paradoxically a proapoptotic protein. ${ }^{32}$ Cleavage of XIAP produces a fragment with a reduced ability to inhibit caspases. $^{38}$ XIAP was cleaved and downregulated early in differentiation (48 h; Figure 4a). In contrast, Livin underwent cleavage only at the late stage of differentiation $(96 \mathrm{~h}$; Figure 4a).

LAMA-84 cells were stably transfected to overexpress wild-type (WT) Livin, a mutated form Livin-RING (that lacks the proapoptotic activity of tLivin), or an empty vector (EV) control. Measuring caspase-3 enzyme activity at day 4 showed that overexpression of Livin induced caspase-3 activation in LAMA-84 cells (black bar; Figure 4b). We next investigated whether the proapoptotic tLivin is responsible for the caspase-3 activation during LAMA-84 MK differentiation using a Livin protein mutant, with a point mutation in the RING domain (Livin-RING). tLivin requires an intact RING domain for its proapoptotic function. ${ }^{33,39}$ Caspase-3 activity was significantly reduced in LAMA-84 cells containing Livin-RING (gray bar; Figure 4b) compared with those containing WT Livin. LAMA-84 cells that overexpressed the WT Livin $(P<0.035)$ or Livin-RING $(P=5.0 \mathrm{E}-05)$ produced more PLPs as compared with control cells (Figure 4c). Interestingly, overexpression of the Livin-RING mutant that lacks the proapoptotic activity of tLivin produce more PLP compared with WT Livin $(P<0.031)$ (Figure $4 \mathrm{c})$; however, the overexpression of the mutant form of tLivin showed a reduced ability of MKs to produce functional a
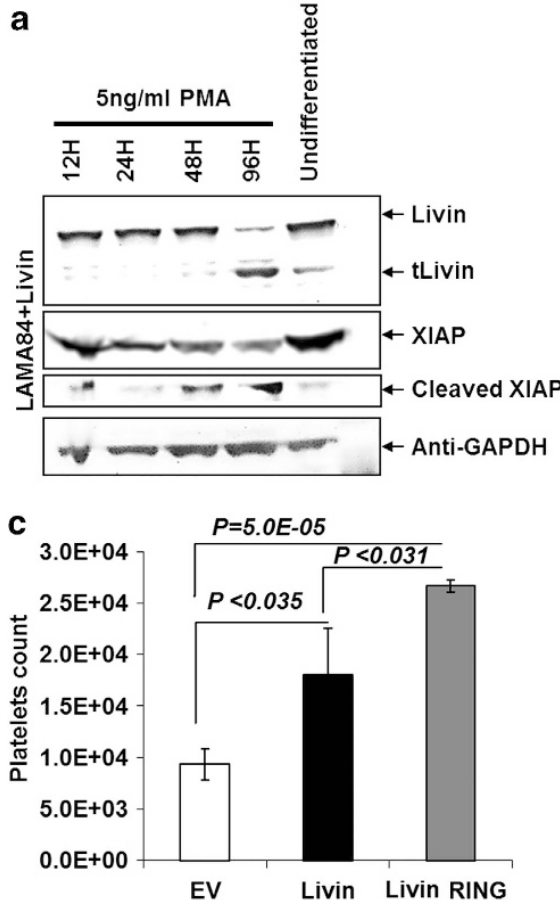

b
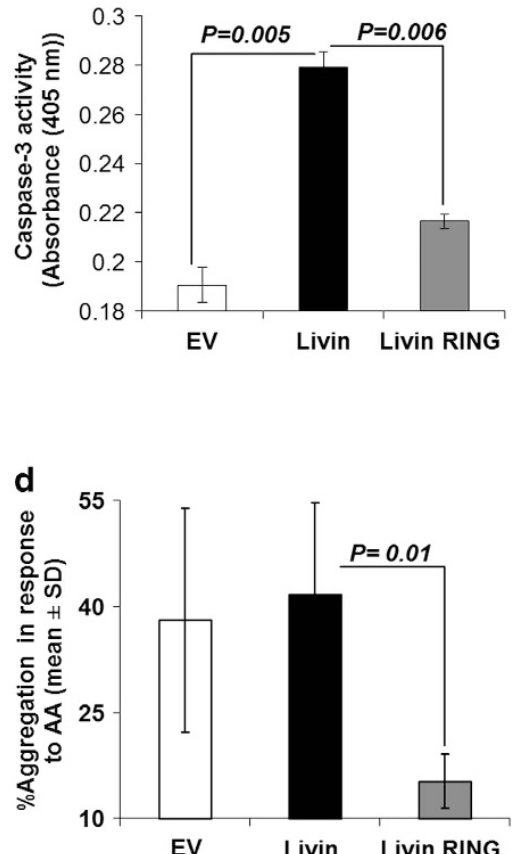

Figure 4 The proapoptotic activity of Livin is required for the generation of functional platelets. Control LAMA-84 cells (EV, empty vector) and LAMA-84 cells stably overexpressing WT Livin or Livin mutant lacking proapoptotic activity (Livin-RING) were treated with PMA for 4 days. Cells were harvested at 12, 24, 48 and $96 \mathrm{~h}$. (a) Western blot analysis of Livin and XIAP proteins and their cleaved derivatives during LAMA-84 differentiation into MKs. Note the appearance of cleaved proapoptotic tLivin after 96 hours of differentiation induction with PMA. (b) Caspase-3 activation was assessed through the evaluation of caspase-3 enzyme activity (100 ng of protein) with Ac-DEVDpNA (N-acetyl-Asp-Glu-Val-Asp-p-nitroaniline) in a colorimetric assay at day 4. Note that Livin transfection enhanced the caspase activity. (c) At day 4, culture-derived PLPs were collected from the medium for flow cytometric analysis of CD41 expression and the number of CD41+ platelet particles was quantitated. The PLP counts from cells transfected with either Livin or Livin-RING were significantly increased $(n=3)$. (d) Functional assay for PLPs' aggregation in response to arachidonic acid (AA) was performed to determine the potential biological activity of these PLPs produced by LAMA- 84 cells. Both control and Livin transfectants produced functional PLPS, whereas those derived from the Livin-RING-transfected cells were not functional $(n=4)$ 
PLPs, measured by platelet aggregation $(P=0.01)$ (gray bar; Figure 4d).

Overexpression of Livin in human CD34 + cells increase megakaryocytic endoreplication and differentiation. To investigate the effect of Livin on primary MK progenitors, CD34 + cells isolated from the cord blood were transduced with Livin, Livin-RING or control empty vector and grown for 14 days under MK-differentiating conditions with the addition of stem cell factor (SCF) and thrombopoietin (TPO). ${ }^{40}$

At day 14 , the CD34 + cells showed a marked increase in cell size and underwent polyploidization (Figure 5a). The percentage of cells stained for MK marker (CD41+; Figure $5 \mathrm{~b}$ ) increased in the Livin-overexpressing CD34+ cells compared with control cells containing empty vector (3.7 \pm 1 -fold, $P=0.029$; Figure $5 \mathrm{c}$ ). The differentiated CD41 + cells at day 14 expressed 100\% CD45 and were also $\mathrm{CD} 33+$ (control $=7.4+6.9 \%$, overexpressing Livin $=22.6+39.8 \%$ and overexpressing Livin-RING $12.1+14 \%, n=9)$. In addition, there was a significant increase in multinucleated MKs at day 14 of culture as assessed by morphological analysis on May-Grunwald/ Giemsa-stained cytospins in CD34 + differentiation cultures overexpressing Livin $(P=0.01$, number of nuclei $\geq 4$, black bar; Figure $5 \mathrm{~d}$ ). The presence of multinucleated cells in the cytospin preparation is indicative of the presence of polyploidy MKs. Interestingly, there was no difference in platelet production between primary MKs that were overexpressing LivinRING compared with empty vector and CD34+ cells differentiated with TPO and SCF factor alone (Figure 5d).
Assessment of the presence of Livin, and its cleaved protein tLivin, at the terminal stages of primary MK progenitors maturation (day 14) showed robust levels in the CD34+ cultures that overexpressed Livin (Figure 5e).

Overexpression of Livin in primary MK progenitors produces significantly more functional platelets. To determine whether platelets were produced from the primary MKs progenitors, the presence of CD41+ low forward scatter and side scatter platelets released into the media were studied using flow cytometry. Normal platelets from cord blood were used to establish the gates for analysis (Figure 6a) and as a positive control for CD41 + staining. As expected, the majority ( $>85 \%$ ) of cord blood-derived platelets expressed CD41 (Figure 6a). Platelets derived from primary MKs culture were analyzed for CD41 expression (Figure 6b). The CD41 + platelets detected also expressed CD42b (data not shown). Compared with control cells, primary MKs that overexpressed the WT Livin or Livin-RING produced more platelets $(4.3 \pm 1$-fold, $P=0.02$ and $3 \pm 0.5$ fold, $P=0.03$ as compared with empty vector control, respectively; Figure 6c). However, only platelets produced by the overexpressing WT Livin show activity in response to arachidonic acid (AA) presence by the upregulation of CD62p (see Materials and Methods), whereas the platelets produced in the overexpressing mutant Livin-RING protein show no activation and thus not functional (Figure 6d).

Knockdown of Livin reduces the ability of MKs to produce functional platelets. To further verify our findings, small interfering RNA (siRNA) was used to knockdown the

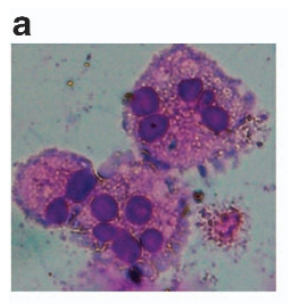

d

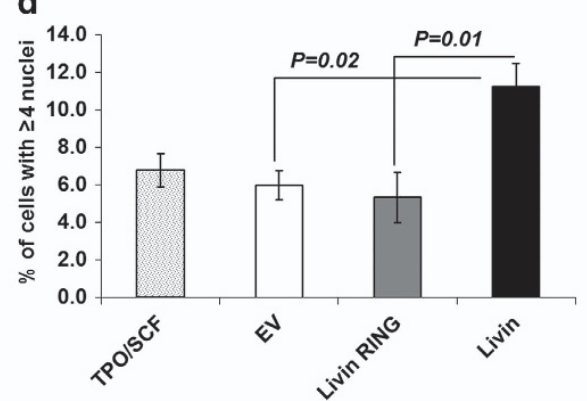

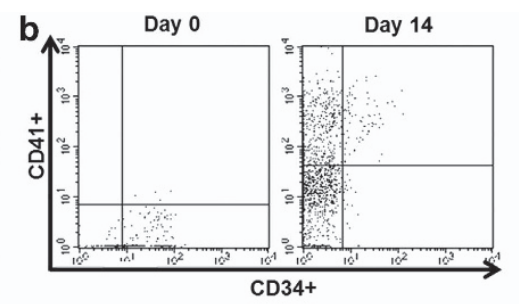

e
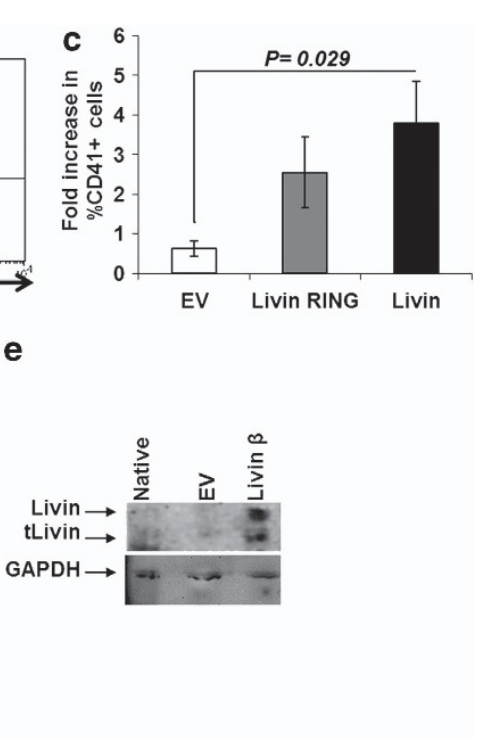

Figure 5 Cord blood CD34 + cells overexpressing Livin show increased differentiation toward the megakaryocytic lineage and higher ploidy. Cord blood CD34 + cells were cultured with TPO and SCF to drive MK differentiation. After one day, the cells were infected with control, WT Livin or RING mutant-expressing retroviruses. (a) At day 14, May-Grunwald/Giemsa staining of cytospin preparations showing polyploid MKs $(n=6)$ (original magnification, $\times 60$ ). (b) Dot plots of days 0 and 14 differentiated CD34 + cells stained for MK marker (CD41,$+ n=6$ ). (c) CD41 + cell production was increased in CD34 + cells infected with Livin as compared with CD34 + cells incubated with TPO and SCF alone $(n=6)$. (d) At day 14, the nuclei of MKs generated from CD34 + cells were counted in cytospins of cells stained with May-Grunwald/Giemsa to assess ploidy $(n=6)$. (e) Western blot analysis of Livin protein expression in undifferentiated CD34 + cells (naive) and cells differentiated for 14 days with TPO and SCF and with infected empty vector or plasmid containing Livin. Note the appearance of cleaved proapoptotic thivin after 14 days of differentiation 


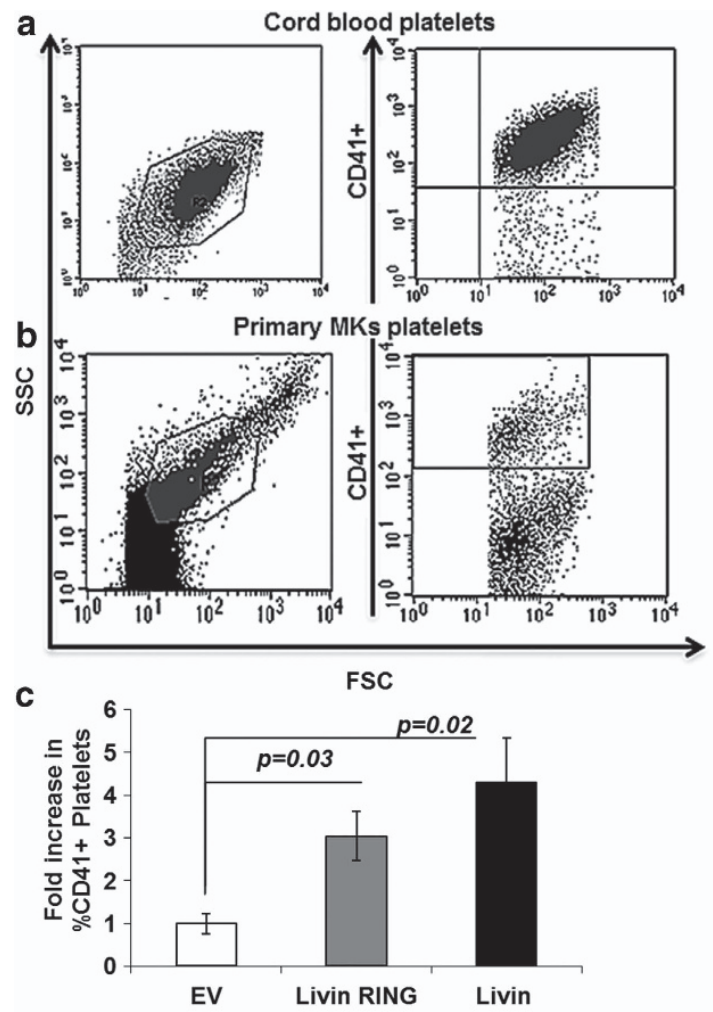

d

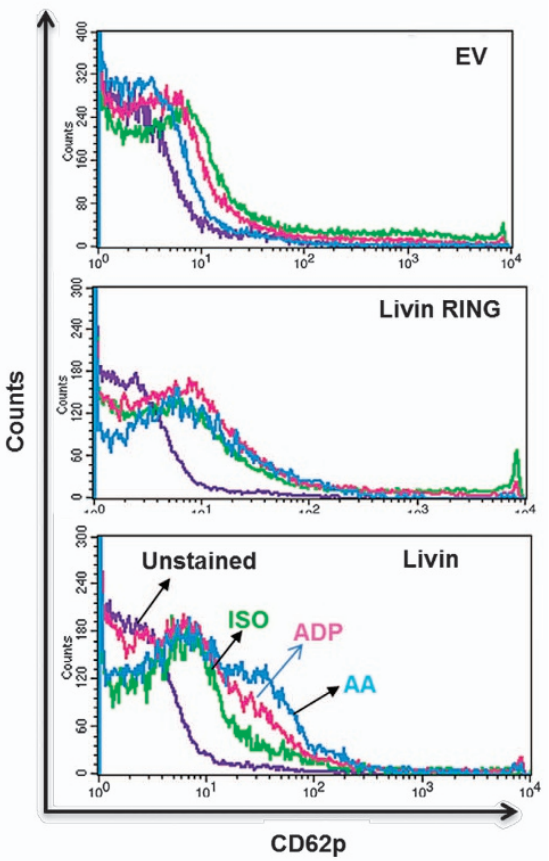

Figure 6 MKs derived from cord blood CD34 + cells overexpressing Livin or Livin-RING mutant produce more platelets in comparison with control. At day 14, platelets generated from MKs differentiated from CD34 + cells overexpressing either WT Livin, antiapoptotic-only Livin-RING or empty vector (control) were collected from the supernatant and analyzed for CD41 expression and platelet activation $(n=6)$. (a) Platelets from cord blood were used to establish the gates for flow cytometric analysis. (b) Platelets generated from CD34 + cultures were similar in forward scatter, side scatter and CD41 expression. (c) The fold expansion of the percent of CD41 + platelets derived from CD34 + cells infected with WT Livin or antiapoptotic only Livin-RING as compared with empty vector. (d) Platelets derived from MK cultures $(n=4)$ were incubated with ADP or arachidonic acid (AA) for $10 \mathrm{~min}$ at room temperature. Platelets were stained with anti-CD62p or isotype control to detect the activation of the platelets and analyzed on a flow cytometer. Iso, isotype control

expression of endogenous Livin in LAMA-84 and CD34 + cells using a construct containing Livin SiRNA (pSUPER-Livin-2), which was previously characterized as a specific and efficient inhibitor of Livin expression. ${ }^{41}$ First, western blot analyses were performed 4 days after treatment with PMA on LAMA-84 cells that were transfected with Livin siRNA. Indeed, Livin protein levels were significantly reduced by pSUPER-Livin-2, in comparison with control (pSUPER-luc) (Figure 7a). Differentiated LAMA-84 cells that were downregulated for Livin protein produced significantly less PLPs during MK differentiation as compared with control cells $(P=0.0095)$ (Figure $7 \mathrm{~b})$. The extent of PLPs aggregation in response to ADP or collagen was similar in the control and pSUPER-Livin-2-transfected cells. However, PLPs produced from LAMA-84 cells that were downregulated for Livin had a reduced ability to aggregate in response to epinephrine $(P=0.0087)$ or AA $(P=0.00016)$ (Figure 7c). Downregulation of the Livin protein in CD34 + cells significantly decreased the number of multinucleated primary MK progenitors generated at day $14(P=0.033$; Figure $7 d)$. The extent of platelets aggregation in response to ADP was similar in the primary MK progenitors as compared with MK cells infected with pSUPER-Livin-2. However, platelets produced from primary MK progenitor cells that were downregulated for Livin had a reduced ability to aggregate in response to AA and thus showed less functionality (Figure 7e).

\section{Discussion}

Livin appears to use its apoptotic machinery to have a differential regulatory role in MK development and platelet production. We report for the first time that Livin is clearly detected by immunohistochemical staining in normal mature BM MKs and has a role in MK differentiation and platelet production. Myeloid and megakaryocytic leukemia cell lines stimulated with PMA serve as useful models for MK activation and differentiation in vitro. These cells can undergo differentiation to both megakaryocytic and erythroid lineages depending on the stimulus: PMA stimulates megakaryocytic differentiation, ${ }^{42}$ whereas hemin induces erythroid differentiation of these cells. ${ }^{36}$ Owing to the scarcity of MKs in normal human tissue, we initially used PMA to induce differentiation and maturation of the multipotential myeloid leukemic LAMA-84 cell line ${ }^{37}$ to assess the role of Livin in thrombopoiesis. Differentiation was accompanied by changes in cell morphology, polyploidization and acquisition of specific MK markers (CD41). We report for the first time that upon differentiation LAMA-84 cells formed proplatelets and produced functional PLPs capable of aggregation and thus function as normal platelets (Figures 2 and 3). We also found that Livin overexpression increased the ability CD34 + progenitor cells to differentiate into MKs. The MK cells produced showed significantly higher ploidy (Figures $5 \mathrm{a}$ and $\mathrm{d}$ ) and increased 

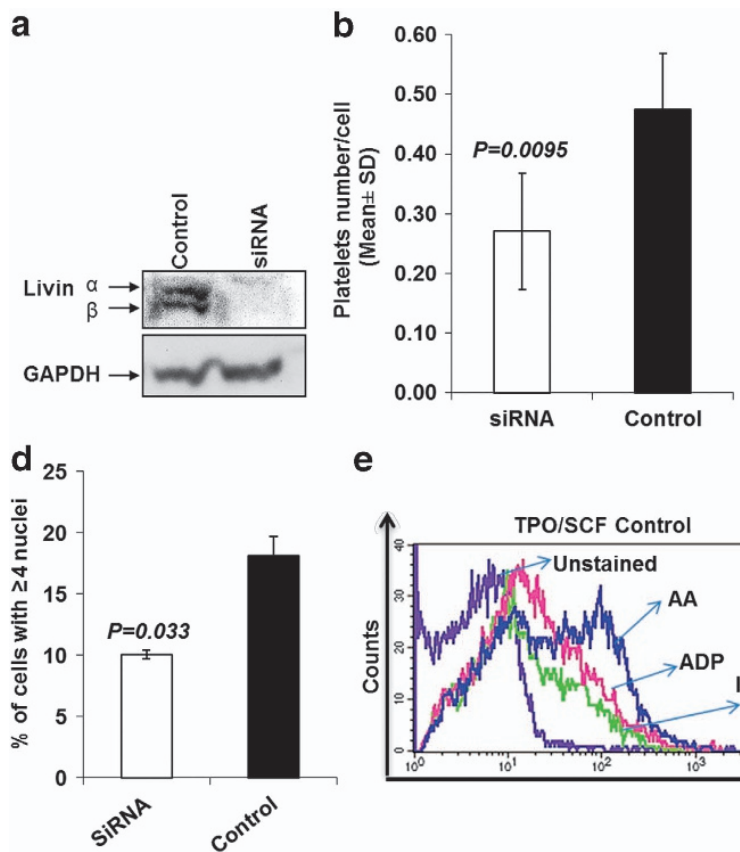

e

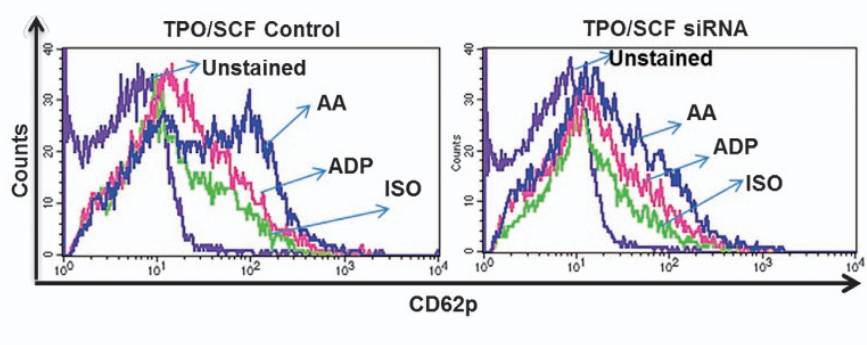

C

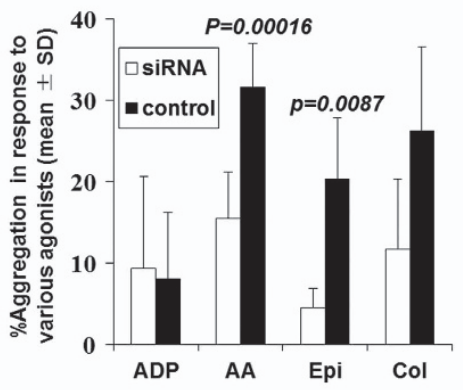

TPO/SCF SIRNA

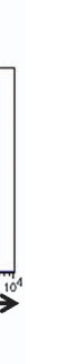

Figure 7 The effect of the knockdown of Livin on platelets production and function. Downregulation of Livin expression was performed in both LAMA-84 cells (a-c) and cord blood CD34 + cells ( $\mathbf{d}$ and $\mathbf{e}$ ) with the use of pSUPER-Livin-2 or control vector (pSUPER-Luc). (a) Western blot analysis showing the downregulation of both $\alpha$ - and $\beta$-Livin expression in LAMA-84 cells. (b) Knockdown of Livin in LAMA-84 cells reduced the number of PLPs (PLPs count/LAMA-84 cells count) ( $n=5$ ). (c) Aggregation induced by various agonists (ADP $(n=7)$, arachidonic acid (AA) $(n=7)$, epinephrine (Epi) $(n=4)$ and collagen $($ Col) $(n=4))$ is reduced in Livin-knockdown cells. (d) At day 14 , the nuclei of MKs generated from CD34 + cells were counted in cytospins of cells stained with May-Grunwald/Giemsa $(n=3)$. (e) Platelets derived from CD34 + cells differentiated toward MKs with and without the downregulation of Livin expression were incubated with ADP or AA and were stained with anti-CD62p to detected platelet activation $(n=3)$. Iso, isotype control

their ability to produce functional platelets (Figure 6). Livin was cleaved at the terminal differentiation of LAMA-derived (Figure 4a) and primary MKs (Figure 5e). Moreover, overexpression of the Livin-RING mutant in both CD34+ and LAMA-84 cells (Figures $4 c$ and $6 c$, respectively) increased the ability of the differentiating cells into MK lineage to produce platelets. However, Livin-RING mutant reduced the ability of primary MK progenitors and LAMA-84 to generated functional platelets shown by a decrease in activity in response to $A A$ (Figures 4d and 6d, respectively).

Recent studies showed that both mRNA and protein of the IAP survivin were found to be significantly downregulated in MKs as compared with differentiating erythroid cells. ${ }^{43}$ Using a proteomic approach, Cailleteau et al. ${ }^{44}$ observed downregulation of cellular IAP-1 (CIAP-1) and XIAP expression and increased expression of SMAC/Diablo after diosgenininduced megakaryocytic differentiation of HEL cells, an erythroleukemic cell line, and during the subsequent apoptosis of mature MKs. ${ }^{44}$ The LAMA-84 in vitro model shows downregulation of the antiapoptotic proteins XIAP and survivin during differentiation into the megakaryocytic lineage (Figure 2e) in agreement with other reports. ${ }^{43-46}$ In contrast, we find that Livin is upregulated during differentiation of LAMA-84 into MKs but not into the erythrocytes (Figure 2e).

Caspases form the core activation of apoptotic cell death. In addition, caspases have an important role in non-apoptotic functions. Previous studies suggest that caspases have an active role in the differentiation of erythroblasts, lens epithelial cells and keratinocytes. ${ }^{47}$ Several studies suggest distinct mechanisms that might explain why caspase activation leads to apoptosis in some cases and to differentiation in others. ${ }^{48}$ Those mechanisms include temporal restriction (transient wave of caspase-3 activation during developmental erythropoiesis) and substrate specificity (as demonstrated in several models of cellular differentiation). ${ }^{48}$ de Botton et al. ${ }^{10}$ have shown that during MK differentiation, there are two forms of caspase activation. The first, before proplatelet formation, involves 'localized' caspase-3 activation with the release of cytochrome $c$ into the cytosol and without DNA fragmentation (a hallmark of apoptotic cells). The second is at the terminal stages of MK maturation, in senescent MKs, where diffuse caspase-3 activation induces classic apoptosis. ${ }^{10}$

Several studies suggest that IAPs, which function as caspase inhibitors, can also inhibit the process of differentiation. For example, overexpression of C-IAP1 interferes with differentiation of the human acute monocytic leukemia cell line (THP1) into macrophages. ${ }^{49}$ Measuring caspase-3 enzyme activity at day 4 demonstrated that overexpression of Livin induced caspase- 3 activation at the later stages of maturation of LAMA-84 into MK (Figure 4b).

Recent studies have demonstrated that the caspase-IAP interaction is more diverse than first believed, with both antiand proapoptotic consequences. $\mathrm{XIAP}^{38}$ and Livin $^{32}$ are specifically cleaved by effector caspases during apoptosis. Although cleavage of XIAP produces fragments with reduced ability to inhibit caspases, ${ }^{38}$ caspase-mediated cleavage converts Livin from an anti- to a proapoptotic factor. ${ }^{39}$ In the LAMA-84 model, we observed a decrease in the full-length form of XIAP protein in the differentiated MKs. This observation has been described previously. ${ }^{38}$ Here we show for the 
first time that this decrease is due to cleavage of XIAP, followed by appearance of a $30 \mathrm{kDa}$ fragment of XIAP with reduced ability to inhibit caspases.

It is reasonable to assume that IAPs may block the process of differentiation. In LAMA-84 cells overexpression of Livin, which possesses both pro- and antiapoptotic activities, did not suppress the differentiation program, as measured by the production of functional platelets. We observed a decrease in the antiapoptotic full-length form of Livin during the differentiation of LAMA-84 cells toward MKs, followed by the appearance of the proapoptotic product tLivin. Moreover, LAMA-84 cells overexpressing the Livin-RING mutant, which possesses only the antiapoptotic activity, did not induce caspase- 3 activation in LAMA-84 cells (Figure 4b). Here we propose that the antiapoptotic Livin has a role in thrombopoiesis, possibly by reducing early caspase- 3 activity and inhibiting MK apoptosis at its early stage of differentiation. At terminal stages of MK maturation, Livin cleavage and accumulation of thivin allows apoptosis to occur simultaneously with platelet production. We believe it is the balance between Livin and tLivin that enables more MKs to be produced as well as more platelets. The antiapoptotic effect of Livin helps differentiation, whereas the apoptotic effects of tLivin induce more ploidy that in turn generated more platelets.

Although the association between platelets activation and apoptosis is not well defined, ${ }^{50}$ caspase inhibition decreases both platelet phosphatidylserine exposure ${ }^{51}$ and aggregation, whereas the intrinsic apoptosis pathway has a major role in regulating apoptosis-like events in platelets. ${ }^{6}$ Furthermore, some platelet agonists can stimulate both caspase- 9 and -3 activation in human platelets, ${ }^{51}$ while in contrast in vitro treatment with zVAD-fmk, a pancaspase inhibitor, significantly decreased platelet aggregation. ${ }^{52}$

Downregulation of tLivin protein either by siRNA (Figure 7) or by overexpression of the Livin-RING mutant, which lacks the proapoptotic activity of tLivin (Figures $4 d$ and $6 d$ ), reduced the ability of platelets to aggregate in response to AA. This suggests that thivin has a role in platelets' activation by regulating the apoptosis pathway in platelets. Activation of platelets leads to their shedding of microparticles; ${ }^{53}$ in our study, we did not find a significant difference in the production of microparticles between platelets generated from cells overexpressing the Livin protein to that of empty vector. However, there is a trend of increased microparticles in the Livin-overexpressing cultures (data not shown).

Pancytopenia and prolonged thrombocytopenia remains a significant clinical challenge for patients undergoing hematopoietic stem cell transplantation and high-dose chemotherapy. Engraftment of transplanted cells or regeneration of normal hematopoiesis and blood count recovery is usually accomplished within 2 to 5 weeks, during which period the patient is susceptible to life-threatening infections and bleeding. Large numbers of platelet transfusions are needed during this period owing to extended time for platelets to recover. The reason for this delay has been attributed to insufficient MK precursors in the grafts. ${ }^{40}$ Injections of thrombopoietin, the physiologic regulator of thrombopoiesis, to increase the platelet count has not been clinically effective owing to the paucity of MK progenitors in the grafts. ${ }^{54}$ The role of Livin in thrombopoiesis has clearly been defined in the study. Livin could potentially be the protein necessary to improve engraftment of platelets by either stimulation of part of the graft with Livin before transplantation or enabling hematopoietic cells to produce platelets in vitro as an alternative source of single donor platelets.

\section{Materials and Methods}

Cell culture. LAMA-84 cells were maintained in RPMl1640 with $10 \%$ fetal calf serum, $100 \mathrm{U} / \mathrm{ml}$ penicillin, $100 \mu \mathrm{g} / \mathrm{ml}$ streptomycin and $2 \mathrm{mM}$ glutamine. Cord blood samples were obtained from public sources with Hadassah IRB ethics committee approval and CD34 + cells separated within $48 \mathrm{~h}$ of collection.

Separation of CD34 + cells from cord blood. Mononuclear cells (MNCs) were isolated by density gradient centrifugation using Ficoll-Paque (GE Healthcare Bio-Science AB, Pittsburgh, PA, USA). Adherent monocytes were depleted from the MNC fraction by $90 \mathrm{~min}$ incubation at $37^{\circ} \mathrm{C}$ and removal of adherent cells. Residual platelets were removed by centrifugation of remaining MNCs over fetal calf serum. ${ }^{55} \mathrm{CD} 34+$ cell enrichment was performed using either the Diamond or Microbeads CD34 isolation kit (Miltenyi Biotec Inc., Auburn, CA, USA) according to the manufacturer's protocol. Purity of CD34 + fraction was assessed by flow cytometry and in all cases was higher than $85 \%$ with all CD41 expression present exclusively on $\mathrm{CD} 34+$

Identification of MK differentiation. LAMA-84 eyrthroleukemia cells were induced to differentiate to MKs with $0.6-5 \mathrm{ng} / \mathrm{ml} \mathrm{PMA}$ and were harvested 4 days after treatment and analyzed. The CD34 + cells were cultured in Iscove's medium (IMDM) $\left(1 \times 10^{5} \mathrm{cells}\right.$ per well) and differentiated into MKs in the presence of $10 \mathrm{ng} / \mathrm{ml} \mathrm{SCF}$ and $50 \mathrm{ng} / \mathrm{ml}$ TPO. Cytokines were added every 3 days, fresh. Culture cells were analyzed on day 14.

Retroviral vectors and infections. We generated retroviral constructs by subcloning the Livin cDNA into the pWZL IRES-blasticidin vector. Livin mutants were described previously. ${ }^{39}$ The 293T cells were established to produce virus and supernatant from 48 and $72 \mathrm{~h}$ were infected into both LAMA-84 and CD34 + cells during their differentiation. To overexpress Livin both LAMA-84 and CD34 + cells were infected after one day of differentiation with pWZL IRES-blasticidin vector expressing Livin, Livin-RING or empty vector. In experiments downregulating Livin expression, LAMA-84 were transfected by electroporation with pSUPER-Livin-2 (Livin siRNA) or pSUPER-luc (control siRNA) vectors (kindly supplied by Dr Karin Hoppe-Seyler ${ }^{41}$ ) together with pWZL IRES-blasticidin one day after differentiation was initiated. For downregulating Livin expression in CD34 + cells, cells were infected one day after differentiation with supernatant containing virus generated by $293 \mathrm{~T}$ cells.

Analysis of MK maturation. To determine the extent of maturation toward MKs, $1 \times 10^{6}$ cultured cells (LAMA-84 and CD34 + cells) were washed and then labeled with (a) anti-CD41-FITC (Gpllb/llla; BD Bioscience, San Jose, CA, USA) or anti CD71-FITC or (b) anti-CD33-FITC, anti-CD41-PE, anti-CD45-PerCp and CD34-APC (Beckman Coulter, Fullerton, CA, USA), and analyzed for the percentage of $\mathrm{CD} 41$ cells generated.

To determine the amount of ploidy, differentiated LAMA-84 cells were fixed overnight in $75 \%$ ethanol at $4{ }^{\circ} \mathrm{C}$ and labeled with propidium iodide (PI, $50 \mu \mathrm{g} / \mathrm{ml}$ ) and analyzed using the FACScalibur (Becton Dickinson), whereas day 14 differentiated CD34 + cells were analyzed quantitatively under a microscope after May-Grunwald/Giemsa staining by quantitating the number of nuclei per cell and specific morphology of MKs with this stain. Only cells with MK morphology were analyzed. The presence of multinucleated cells in the cytospin preparation is indicative of the presence of polyploidy MKs. Differentiated CD34 + cells were assessed for the presence of multinucleated mature MKs by morphology. Owing to heterogeneity of cells produced in the CD34 + cultures, assessment of MK ploidy by flow cytometry is not accurate.

Isolation of human blood platelets. Samples of normal blood (Hadassah IRB ethics approval) and cord blood were collected in tubes containing acid-citrated-dextrose (ACD) solution (2.5\% trisodium citrate, $1.5 \%$ citric acid and $2 \%$ glucose). Platelet-rich plasma was obtained by centrifugation at $150 \times g$ for $20 \mathrm{~min}$ at room temperature. 
Isolation of PLPs. Platelets released into the differentiated cultures were assessed by collecting the supernatants and identified by flow cytometry. The culture medium was collected and centrifuged at $150 \times g$ for 20 min to remove the nucleated cells. The supernatant was centrifuged at $500 \times g$ for $20 \mathrm{~min}$ to pellet the platelets. Sediments containing platelets and PLPs were resuspended in the culture medium in $500 \mu \mathrm{l}$ aliquots and were labeled with anti-CD41-FITC and log amplification of forward scatter and side scatter.

Platelet aggregation to test functionality. PLPs were tested for their functionality in aggregation assays using an AGGRAM aggregometer (Helena Laboratories, Beaumont, TX, USA) according to the manufacturer's instructions using various agonists. Aggregation of platelets in the platelet-poor plasma was measured in response to $\operatorname{ADP}(11 \mu \mathrm{M}) \mathrm{AA}(1.6 \mu \mathrm{M})$, epinephrine $(50 \mu \mathrm{M})$ or ristocetin $(1.6 \mathrm{mM})$ (all purchased from Diamed AG, Morat, Switzerland) and collagen $(5 \mu \mathrm{g} / \mathrm{ml})$ (Helena Laboratories). As the number of platelets generated from CD34 + cultures is low, platelets derived from these cultures were stimulated for 15 min at RT with ADP or AA and activation was assessed by flow cytometry with Abs specific to detect activation, that is, upregulation of CD62P (P-selectin). ${ }^{56}$

Western blot analysis and immunoprecipitation. Whole-cell lysates were prepared from $0.25-1 \times 10^{6}$ cultured cells using $100 \mu$ lysis buffer $(20 \mathrm{mM}$ Tris-HCl, $2 \mathrm{mM}$ EDTA, $6 \mathrm{mM} \beta$-mercaptoethanol, $1 \%$ Nonidet P-40, 0.1\% SDS and protease inhibitors at $4{ }^{\circ} \mathrm{C}$ for $20 \mathrm{~min}$, with vigorous vortex mixing). Antibodies used were as follows: monoclonal antibody against Livin (clone 88C570) (Imgenex, San Diego, CA, USA) diluted 1:3000 and survivin 6E4 monoclonal antibody (Cell Signaling Technology, Danvers, MA, USA). For these antibodies, Envision-HRP (DAKO, Glostrup, Denmark) was used as a secondary antibody. For polyclonal antibody against XIAP (Cell Signaling Technology), anti-rabbit IgG HRP-linked antibody (Cell Signaling Technology) was used as a secondary antibody.

For immunoprecipitation, equal amounts of protein lysates were precleared with Protein A/G-Agarose (Santa Cruz Biotechnology, Santa Cruz, CA, USA) together with $1 \mu \mathrm{g}$ of mouse $\mathrm{IgG}$. Livin was immunoprecipitated from the cleared lysates (Imgenex; clone 88C570) and the immune complexes were precipitated with Protein A/G-Agarose.

Caspase- 3 activity. Extracts from $1 \times 10^{6}$ cells were prepared by the freeze-thaw method and assayed for caspase-3 activity using CaspACE Assay System, Colorimetric (Promega, Madison, WI, USA).

Immunohistochemistry. The use of archived human tissue and platelets in this study was approved by the Institutional Review Board of the Helsinki Committee at Hadassah-Hebrew University Medical Center. Five-micrometer-thick tissue sections of formalin-fixed, paraffin-embedded normal BM aspiration samples were deparaffinized and endogenous peroxidase was quenched with $3.3 \%$ hydrogen peroxide for $10 \mathrm{~min}$ at room temperature. Sections were blocked with a $3 \%$ goat serum in $50 \mathrm{mM}$ Tris, $\mathrm{pH} 7.4$, for $20 \mathrm{~min}$. The slides were then incubated with a 1: 100 dilution of 3 F9 monoclonal antibody against Livin ${ }^{34}$ in $50 \mathrm{mM}$ Tris, $\mathrm{pH}$ 7.4 , and $3 \%$ goat serum overnight, washed and incubated with a goat anti-mouse Ig horseradish peroxidase-conjugated antibody (DAKO) for $30 \mathrm{~min}$. The slides were developed with $D A B$ as the chromogen, placed in an enhancing solution (Zymed Laboratories, South San Francisco, CA, USA) for $5 \mathrm{~min}$, and counterstained with hematoxylin.

\section{Conflict of Interest}

The authors declare no conflict of interest.

Acknowledgements. We thank Shoshana Baron for assistance with flow cytometry, Eti Zwang for performing platelet function assays and Adi Loya for cloning the LAMA-84 cells. We also thank David Varon's lab. This work was supported by Israel Science Foundation Grant 524/06 and the Gabrielle Rich Leukemia Foundation. IA is a recipient of The Israeli Ministry of Science, PhD scholarship for Israeli Citizens of Arab, Circassian and Druze descent.

1. Gordge MP. Megakaryocyte apoptosis: sorting out the signals. Br J Pharmacol 2005; 145 : 271-273.

2. Ravid K, Lu J, Zimmet JM, Jones MR. Roads to polyploidy: The megakaryocyte example. J Cell Physiol 2002; 190: 7-20.
3. Italiano JE, Lecine $\mathrm{P}$, Shivdasani RA, Hartwig JH. Blood platelets are assembled principally at the ends of proplatelet processes produced by differentiated megakaryocytes. J Cell Biol 1999; 147: 1299-1312.

4. Deutsch VR, Tomer A. Advances in megakaryocytopoiesis and thrombopoiesis: from bench to bedside. Br J Haematol 2013; 161: 778-793.

5. Handagama PJ, Feldman BF, Jain NC, Farver TB, Kono CS. In vitro platelet release by rat megakaryocytes: effect of metabolic inhibitors and cytoskeletal disrupting agents. Am J Vet Res 1987; 48: 1142-1146.

6. Kile BT. The role of the intrinsic apoptosis pathway in platelet life and death. $J$ Thromb Haemost 2009; 7: 214-217.

7. Mason KD, Carpinelli MR, Fletcher JI, Collinge JE, Hilton AA, Ellis S et al. Programmed anuclear cell death delimits platelet life span. Cell 2007; 128: 1173-1186.

8. Zhang H, Nimmer PM, Tahir SK, Chen J, Fryer RM, Hahn KR et al. Bcl-2 family proteins are essential for platelet survival. Cell Death Differ 2007; 14: 943-951.

9. Clarke MCH, Savill J, Jones DB, Noble BS, Brown SB. Compartmentalized megakaryocyte death generates functional platelets committed to caspase-independent death. $J$ Cell Biol 2003; 160: 577-587.

10. de Botton S, Sabri S, Daugas E, Zermati Y, Guidotti JE, Hermine $O$ et al. Platelet formation is the consequence of caspase activation within megakaryocytes. Blood 2002; 100: 1310-1317.

11. Leytin V. Apoptosis in the anucleate platelet. Blood Rev 2012; 26: 51-63.

12. Kaluzhny $Y, Y u$ GG, Sun SS, Toselli PA, Nieswandt B, Jackson CW et al. BclxL overexpression in megakaryocytes leads to impaired platelet fragmentation. Blood 2002; 100: $1670-1678$.

13. Ogilvy S, Metcalf D, Print CG, Bath ML, Harris AW, Adams JM. Constitutive $\mathrm{Bcl}-2$ expression throughout the hematopoietic compartment affects multiple lineages and enhances progenitor cell survival. Proc Natl Acad Sci USA 2003 1999; 96: 14943-14948.

14. Bouillet $P$, Metcalf D, Huang DCS, Tarlinton DM, Kay TWH, Kontgen F et al. Proapoptotic $\mathrm{Bcl}-2$ relative bim required for certain apoptotic responses, leukocyte homeostasis, and to preclude autoimmunity. Science 1999; 286: 1735-1738.

15. Sanz C, Benet L, Richard C, Badia B, Andreu EJ, Prosper F et al. Antiapoptotic protein $\mathrm{BCl}-\mathrm{x}(\mathrm{L})$ is up-regulated during megakaryocytic differentiation of $\mathrm{CD} 34(+)$ progenitors but is absent from senescent megakaryocytes. Exp Hematol 2001; 29: 728-735.

16. Kozuma Y, Kojima H, Yuki S, Suzuki H, Nagasawa T. Continuous expression of Bcl-xL protein during megakaryopoiesis is post-translationally regulated by thrombopoietinmediated Akt activation, which prevents the cleavage of Bcl-xL. J Thromb Haemost 2007; 5: 1274-1282.

17. Josefsson EC, James C, Henley KJ, Debrincat MA, Rogers KL, Dowling MR et al. Megakaryocytes possess a functional intrinsic apoptosis pathway that must be restrained to survive and produce platelets. J Exp Med 2011; 208: 2017-2031.

18. Morison IM, Cramer Borde EM, Cheesman EJ, Cheong PL, Holyoake AJ, Fichelson S et al. A mutation of human cytochrome $c$ enhances the intrinsic apoptotic pathway but causes only thrombocytopenia. Nat Genet 2008; 40: 387-389.

19. White MJ, Schoenwaelder SM, Josefsson EC, Jarman KE, Henley KJ, James C et al. Caspase-9 mediates the apoptotic death of megakaryocytes and platelets, but is dispensable for their generation and function. Blood 2012; 119: 4283-4290.

20. Winkler J, Rand ML, Schmugge M, Speer O. Omi/HtrA2 and XIAP are components of platelet apoptosis signalling. Thromb Haemost 2013; 109: 532-539.

21. Du CY, Fang M, Li YC, Li L, Wang XD. Smac, a mitochondrial protein that promotes cytochrome $c$-dependent caspase activation by eliminating IAP inhibition. Cell 2000; 102: 33-42.

22. Verhagen AM, Ekert PG, Pakusch M, Silke J, Connolly LM, Reid GE et al. Identification of DIABLO, a mammalian protein that promotes apoptosis by binding to and antagonizing IAP proteins. Cell 2000; 102: 43-53.

23. Suzuki Y, Imai Y, Nakayama H, Takahashi K, Takio K, Takahashi R. A serine protease, HtrA2, is released from the mitochondria and interacts with XIAP, inducing cell death. Mol Cell 2001; 8: 613-621.

24. Hegde R, Srinivasula SM, Zhang ZJ, Wassell R, Mukattash R, Cilenti L et al. Identification of Omi/HtrA-2as a mitochondrial apoptotic serine protease that disrupts inhibitor of apoptosis protein-caspase interaction. J Biol Chem 2002; 277: 432-438.

25. Salvesen GS, Duckett CS. IAP proteins: blocking the road to death's door. Nat Rev Mol Cell Biol 2002; 3: 401-410.

26. Chai J, Shiozaki E, Srinivasula SM, Wu Q, Dataa P, Alnemri ES et al. Structural basis of caspase-7 inhibition by XIAP. Cell 2000; 104: 769-780.

27. Huang Y, Park YC, Rich RL, Segal D, Myszka DG, Wu H. Structural basis of caspase inhibition by XIAP: differential roles of the linker versus the BIR domain. Cell 2000; 104: 781-790.

28. Nachmias B, Ashhab Y, Ben-Yehuda D. The inhibitor of apoptosis protein family (IAPs): an emerging therapeutic target in cancer. Semin Cancer Biol 2004; 14: 231-243.

29. Ashhab Y, Alian A, Polliack A, Panet A, Ben Yehuda D. Two splicing variants of a new inhibitor of apoptosis gene with different biological properties and tissue distribution pattern. FEBS Lett 2001; 495: 56-60.

30. Vucic D, Stennicke HR, Pisabarro MT, Salvesen GS, Dixit VM. ML-IAP, a novel inhibitor of apoptosis that is preferentially expressed in human melanomas. Curr Biol 2000; 10: 1359-1366.

31. Kasof GM, Gomes BC. Livin, a novel inhibitor of apoptosis protein family member. J Biol Chem 2001; 276: 3238-3246. 
32. Nachmias B, Ashhab Y, Bucholtz V, Drize O, Kadouri L, Lotem M et al. Caspase-mediated cleavage converts Livin from an antiapoptotic to a proapoptotic factor: implications for drug-resistant melanoma. Cancer Res 2003; 63: 6340-6349.

33. Abd-Elrahman I, Hershko K, Neuman T, Nachmias B, Perlman R, Ben-Yehuda D. The inhibitor of apoptosis protein Livin (ML-IAP) plays a dual role in tumorigenicity. Cancer Res 2009; 69: 5475-5480.

34. Schmollinger JC, Vonderheide RH, Hoar KM, Maecker B, Schultze JL, Hodi FS et al. Melanoma inhibitor of apoptosis protein (ML-IAP) is a target for immune-mediated tumor destruction. Proc Natl Acad Sci USA 2003; 100: 3398-3403.

35. Cheng T, Wang YS, Dai W. Transcription factor egr-1 is involved in phorbol 12-myristate 13-acetate-induced megakaryocytic differentiation of K562 cells. J Biol Chem 1994; 269: 30848-30853

36. Seigneurin D, Champelovier P, Mouchiroud G, Berthier R, Leroux D, Prenant M et al. Human chronic myeloid leukemic cell line with positive Philadelphia chromosome exhibits megakaryocytic and erythroid characteristics. Exp Hematol 1987; 15: 822-832.

37. Champelovier P, Valiron $O$, Michele J, Dominique L, Scigncurin D. Selection and characterization of an erythroeosinophilic subclone (LAMA-87) and an eosinophilic subclone (LAMA-88) from the multipotential cell line LAMA-84. Leuk Res 1994; 18: 903-918.

38. Deveraux QL, Leo E, Stennicke HR, Welsh K, Salvesen GS, Reed JC. Cleavage of human inhibitor of apoptosis protein XIAP results in fragments with distinct specificities for caspases. EMBO J 1999; 18: 5242-5251.

39. Nachmias B, Lazar I, Elmalech M, Abed-El-Rahaman I, Asshab Y, Mandelboim $\mathrm{O}$ et al. Subcellular localization determines the delicate balance between the anti- and pro-apoptotic activity of Livin. Apoptosis 2007; 12: 1129-1142.

40. Pick M, Perry C, Lapidot T, Guimaraes-Sternberg C, Naparstek E, Deutsch V et al. Stressinduced cholinergic signaling promotes inflammation-associated thrombopoiesis. Blood 2006; 107: 3397-3406

41. Crnkovic-Mertens I, Hoppe-Seyler F, Butz K. Induction of apoptosis in tumor cells by siRNA-mediated silencing of the livin/ML-IAP/KIAP gene. Oncogene 2003; 22: 8330-8336.

42. Molla A, Berthier R, Chapel A, Schweitzer A, Andrieux A. Beta 1 integrins mediate adheren phenotype of human erythroblastic cell lines after phorbol 12-myristate 13-acetate induction. Biochem J 1995; 309: 491-497.

43. Gurbuxani S, Xu YF, Keerthivasan G, Wickrema A, Crispino JD. Differential requirements for survivin in hematopoietic cell development. Proc Natl Acad Sci USA 2005; 102: 11480-11485.

44. Cailleteau C, Liagre B, Beneytout JL. A proteomic approach to the identification of molecular targets in subsequent apoptosis of HEL cells after diosgenin-induced megakaryocytic differentiation. J Cell Biochem 2009; 107: 785-796.

45. Lordier L, Jalil A, Aurade F, Larbret F, Larghero J, Debili N et al. Megakaryocyte endomitosis is a failure of late cytokinesis related to defects in the contractile ring and Rho/ Rock signaling. Blood 2008; 112: 3164-3174.
46. Wen Q, Leung C, Huang Z, Small S, Reddi AL, Licht JD et al. Survivin is not required for the endomitotic cell cycle of megakaryocytes. Blood 2009; 114: 153-156.

47. Boehm D, Mazurier C, Giarratana M-C, Darghouth D, Faussat A-M, Harmand L et al. Caspase- 3 is involved in the signalling in erythroid differentiation by targeting late progenitors. PLos One 2013; 8: 5 .

48. Galluzzi L, Kepp O, Trojel-Hansen C, Kroemer G. Non-apoptotic functions of apoptosisregulatory proteins. EMBO Rep 2012; 13: 322-330.

49. Plenchette S, Cathelin S, Rebe C, Launay S, Ladoire S, Sordet O et al. Translocation of the inhibitor of apoptosis protein c-IAPI from the nucleus to the Golgi in hematopoietic cells undergoing differentiation: a nuclear export signal-mediated event. Blood 2004; 104: 2035-2043.

50. Gyulkhandanyan AV, Mutlu A, Freedman J, Leytin V. Selective triggering of platelet apoptosis, platelet activation or both. Br J Haematol 2013; 161: 245-254

51. Lin KH, Chang HC, Lu WJ, Jayakumar T, Chou HC, Fong TH et al. Comparison of the relative activities of inducing platelet apoptosis stimulated by various platelet-activating agents. Platelets 2009; 20: 575-581

52. Cohen Z, Wilson J, Ritter L, McDonagh P. Caspase inhibition decreases both platelet phosphatidylserine exposure and aggregation - caspase inhibition of platelets. Thromb Res 2004; 113: 387-393.

53. Vasina EM, Cauwenberghs S, Staudt M, Feijge MA, Weber C, Koenen RR et al. Aging- and activation-induced platelet microparticles suppress apoptosis in monocytic cells and differentially signal to proinflammatory mediator release. Am J Blood Res 2013; 3: 107-123.

54. Kanamaru S, Kawano Y, Watanabe T, Nakagawa R, Suzuya H, Onishi T et al. Low numbers of megakaryocyte progenitors in grafts of cord blood cells may result in delayed platelet recovery after cord blood cell transplant. Stem Cells 2000; 18: 190-195.

55. Pick M, Nagler A, Grisaru D, Eldor A, Deutsch V. Expansion of megakaryocyte progenitors from human umbilical cord blood using a new two-step separation procedure. Br J Haematol 1998; 103: 639-650.

56. Ruf A, Pick M, Deutsch V, Patscheke H, Goldfarb A, Rachmilewitz EA et al. In vivo platelet activation correlates with red cell anionic phospholipid exposure in patients with beta-thalassaemia major. Br J Haematol 1997; 98: 51-56.

(c) (i) $(9)$ Cell Death and Disease is an open-access journal published by Nature Publishing Group. This work is licensed under a Creative Commons Attribution-NonCommercialNoDerivs 3.0 Unported License. To view a copy of this license, visit http://creativecommons.org/licenses/by-nc-nd/3.0/ 